\title{
Chemical, Physical, and Sensory Properties of Dairy Products Enriched with Conjugated Linoleic Acid
}

\author{
E. L. Jones, ${ }^{1}$ K. J. Shingfield, ${ }^{2}$ C. Kohen, ${ }^{1}$ A. K. Jones, ${ }^{2}$ B. Lupoli, ${ }^{2}$ A. S. Grandison, ${ }^{1}$ \\ D. E. Beever, ${ }^{2}$ C. M. Williams, ${ }^{1}$ P. C. Calder, ${ }^{3}$ and P. Yaqoob ${ }^{1}$ \\ ${ }^{1}$ School of Food Biosciences, The University of Reading, Reading RG6 6AP, UK \\ ${ }^{2}$ Centre for Dairy Research, The University of Reading, Reading RG6 6AT, UK \\ ${ }^{3}$ Institute of Human Nutrition, University of Southampton, Bassett Crescent East, \\ Southampton SO16 7PX, UK
}

\begin{abstract}
Recent studies have illustrated the effects of cis9,trans-11 conjugated linoleic acid (CLA) on human health. Ruminant-derived meat, milk and dairy products are the predominant sources of cis-9,trans-11 CLA in the human diet. This study evaluated the processing properties, texture, storage characteristics, and organoleptic properties of UHT milk, Caerphilly cheese, and butter produced from a milk enriched to a level of cis9,trans-11 CLA that has been shown to have biological effects in humans. Forty-nine early-lactation HolsteinBritish Friesian cows were fed total mixed rations containing 0 (control) or $45 \mathrm{~g} / \mathrm{kg}$ (on dry matter basis) of a mixture (1:2 wt/wt) of fish oil and sunflower oil during two consecutive 7-d periods to produce a control and CLA-enhanced milk, respectively. Milk produced from cows fed the control and fish and sunflower oil diets contained 0.54 and $4.68 \mathrm{~g}$ of total CLA/100 $\mathrm{g}$ of fatty acids, respectively. Enrichment of CLA in raw milk from the fish and sunflower oil diet was also accompanied by substantial increases in trans C18:1 levels, lowered C18:0, cis-C18:1, and total saturated fatty acid concentrations, and small increases in $\mathrm{n}-3$ polyunsaturated fatty acid content. The CLA-enriched milk was used for the manufacture of UHT milk, butter, and cheese. Both the CLA-enhanced butter and cheese were less firm than control products. Although the sensory profiles of the CLA-enriched milk, butter, and cheese differed from those of the control products with respect to some attributes, the overall impression and flavor did not differ. In conclusion, it is feasible to produce CLA-enriched dairy products with acceptable storage and sensory characteristics.
\end{abstract}

(Key words: conjugated linoleic acid, butter, cheese, sensory)

Received August 20, 2004.

Accepted April 25, 2005.

Corresponding author: P. Yaqoob; e-mail: p.yaqoob@reading.ac.uk.
Abbreviation key: CLA = conjugated linoleic acid, FAME = fatty acid methyl esters, FSO = basal total mixed ration with $45 \mathrm{~g} / \mathrm{kg}$ (on a DM basis) of a 1:2 (wt/ wt) mixture of fish oil and sunflower oil, HDL = high density lipoprotein, LDL = low density lipoprotein, MUFA = monounsaturated fatty acids, PUFA = polyunsaturated fatty acids.

\section{INTRODUCTION}

Conjugated linoleic acid (CLA) is a generic term used to describe positional and geometric isomers of octadecadienoic fatty acids containing conjugated double bonds. Ruminant meat, milk, and dairy products are the predominant sources of CLA in the human diet (Lawson et al., 2001). Recent studies suggest biological effects of cis-9,trans-11 CLA in humans, which may be relevant to human health (as reviewed in Khosla and Fungwe, 2001; Roche et al., 2001; Terpstra, 2004). For example, cis-9,trans-11 CLA provided in supplements has been demonstrated to decrease lymphocyte activation in a dose-dependent manner in healthy humans, with significant effects at doses $>1.2 \mathrm{~g} / \mathrm{d}$ (Tricon et al., 2004a). At this dose, cis-9,trans-11 CLA also lowered the plasma low density lipoprotein:high density lipoprotein (LDL:HDL) and the total cholesterol:HDL ratios, whereas trans-10,cis-12 CLA increased these ratios (Tricon et al., 2004b). Furthermore, animal studies show anticarcinogenic effects of cis-9,trans-11 CLA, and extrapolation to humans suggests that as little as $0.8 \mathrm{~g} / \mathrm{d}$ of $c i s-9$,trans-11 CLA may be sufficient to inhibit tumor growth (Watkins and Li, 2003). However, caution should be exercised in extrapolating data from these animal studies, since they were conducted using background diets that were low in fat, unlike the human diet, and the effect of cis-9,trans-11 CLA may therefore have been exaggerated. Nevertheless, there is substantial interest in the development of dairy products enriched with cis-9,trans-11 CLA, owing to the universal consumption of these foods (Parodi, 1999). The aim of the current study was to 
produce milk, butter, and cheese that could deliver a daily intake of $1.5 \mathrm{~g} / \mathrm{d}$ of cis-9,trans-11 CLA and to test the products for their physical and sensory characteristics. The intention was not to create commercially viable products, but to produce milk and dairy products that could be used to test whether delivering cis9 ,trans-11 CLA through naturally modified dairy products would have effects on human health similar to encapsulated cis-9,trans-11 CLA without compromising the acceptability and processing characteristics of the milk.

Concentrations of cis-9,trans-11 CLA are higher in milk fat from cows offered fresh vs. conserved forages (Kelly et al., 1998a; Dhiman et al., 1999a), and can also be enhanced with whole oilseeds or oil supplements (Kelly et al., 1998b; Lawless et al., 1998; Chouinard et al., 2001). Fish oil is more effective than plant oils for enhancing milk fat CLA content (Offer et al., 1999; Chouinard et al., 2001), and these responses can be further increased when fish oil is fed in combination with supplements rich in C18:2n-6 (AbuGhazaleh et al., 2002; Whitlock et al., 2002; Abu-Ghazaleh et al., 2003). Nutritional strategies for enhancing the cis-9,trans-11 CLA content also result in milk fat containing lower amounts of saturated fatty acids and greater proportions of monounsaturated fatty acids (MUFA) and polyunsaturated fatty acids (PUFA). Unsaturated fatty acids are more reactive than saturated fatty acids, such that lipids containing relatively high amounts of MUFA and PUFA are more susceptible to oxidation and have a shorter shelf life (Rossell, 1989). Furthermore, modifications in milk fatty acid composition also have a profound effect on the physical and processing properties of milk and dairy products (Palmquist et al., 1993). Several studies have indicated no adverse effects of cis-9,trans-11 CLA enrichment on the acceptability of milk (Baer et al., 2001; Ramaswamy et al., 2001; Avramis et al., 2003; Kitessa et al., 2004; Khanal et al., 2005; Lynch et al., 2005), but there is much less information available on the production of dairy products from CLA-enriched milk. Dhiman et al. (1999b) reported that CLA-enriched milk could be used for the successful manufacture of mozzarella cheese, but the physical or sensory attributes of the CLA-enriched cheese were not evaluated. More recently, the use of CLA-enriched milk was reported to have no significant effects on the flavor characteristics of butter (Baer et al., 2001; Ryhänen et al., 2005), Cheddar cheese (Avramis et al., 2003; Khanal et al., 2005), or Edam cheese (Ryhänen et al., 2005). However, most studies to date have provided a relatively limited sensory evaluation of CLA-enriched dairy products, consisting of scores from acceptability and triangle testing. This study was conducted to assess the organoleptic, sensory, and physical characteristics of UHT milk, butter, and Caerphilly cheese prepared from milk containing high levels of CLA. The physical and chemical attributes of CLA-enriched dairy products were assessed in terms of processing characteristics, texture, storage characteristics, fatty acid composition, and organoleptic properties relative to reference control products manufactured under the same conditions.

\section{MATERIALS AND METHODS}

\section{Experimental Design, Animals, and Diets}

Forty-nine British Friesian cows of (mean \pm SE) 622 $\pm 8.3 \mathrm{~kg}$ live weight, $3.0 \pm 0.18$ parity, and $36 \pm 1.2$ DIM were used. The experiment was conducted over 2 consecutive 7 -d experimental periods. During the first experimental period, cows were offered a basal total mixed ration (control), followed by the same diet containing $45 \mathrm{~g} / \mathrm{kg}$ (on a DM basis) of a mixture (1:2, $\mathrm{wt} / \mathrm{wt}$ ) of fish oil (ultra refined herring and mackerel oil) and sunflower oil (FSO). Oils replaced concentrate ingredients and rations were formulated (Table 1) to satisfy the nutrient requirements of dairy cows producing in excess of $30 \mathrm{~kg}$ of milk/d according to the Agricultural and Food Research Council (1993). Diets were fed ad libitum, and samples of fresh total mixed rations were collected daily during each experimental wk and stored at $-20^{\circ} \mathrm{C}$. Feed samples composited for each experimental week were analyzed for volatile components or dried at $60^{\circ} \mathrm{C}$, ground, and analyzed for chemical composition using accredited and Parliament-approved procedures for feedstuff analysis (Statutory Instruments, 1982, 1985) by a commercial laboratory (Natural Resources Management, Bracknell, UK). Oven DM content was corrected for volatile losses according to Porter et al. (1984). Samples of FO and SO for fatty acid determinations were collected at the end of each experimental week, and stored at $-20^{\circ} \mathrm{C}$ before analysis. Because the inclusion of oils in the diet was expected to increase the unsaturated fatty acid content of milk, vitamin E (DL- $\alpha$-tocopheryl acetate, Roche Vitamins Ltd., Welwyn Garden City, UK) was incorporated (500 IU/kg of DM) into both rations. Corn silage ( $c v$ Hudson) was harvested using a forage harvester fitted with grain crackers and ensiled directly without additive. Refined fish oil (Napro Pharma AS, Brattvaag, Norway) and sunflower oil (KTC Edibles Ltd., Wednesbury, UK) were stored in the dark at $4^{\circ} \mathrm{C}$ prior to incorporation into daily rations.

Animals were housed in a free-stall barn and groupfed daily rations as equal meals at 0830 and 1600 h. Cows had continuous access to water and tracemineralized salt blocks. All experimental procedures 
Table 1. Formulation and chemical composition of experimental diets (g/kg, of DM).

\begin{tabular}{|c|c|c|}
\hline \multirow[b]{2}{*}{ Item } & \multicolumn{2}{|c|}{ Diet } \\
\hline & Control & FSO \\
\hline \multicolumn{3}{|l|}{ Inclusion rate (g/kg of $\mathrm{DM})$} \\
\hline Corn silage & 650.0 & 650.0 \\
\hline Soybean meal & 131.3 & 114.3 \\
\hline Rapeseed meal $^{1}$ & 131.3 & 114.3 \\
\hline Wheat feed (middlings) & 54.7 & 47.7 \\
\hline Blended cane molasses and urea ${ }^{2}$ & 11.0 & 9.6 \\
\hline Fish oil ${ }^{3}$ & 0.0 & 15.0 \\
\hline Sunflower oil ${ }^{4}$ & 0.0 & 30.0 \\
\hline Limestone & 8.0 & 7.0 \\
\hline Minerals and vitamins ${ }^{5}$ & 12.7 & 11.1 \\
\hline Vitamin E premix ${ }^{6}$ & 1.0 & 1.0 \\
\hline $\mathrm{DM}(\mathrm{g} / \mathrm{kg})$ & 420 & 436 \\
\hline \multicolumn{3}{|l|}{ Composition (g/kg of DM) } \\
\hline Organic matter & 930 & 937 \\
\hline Crude protein & 172 & 170 \\
\hline Neutral detergent fiber & 405 & 387 \\
\hline Starch & 177 & 167 \\
\hline Ether extract & 33.5 & 63.0 \\
\hline Metabolizable energy (MJ/kg of DM) & 11.4 & 12.4 \\
\hline
\end{tabular}

${ }^{1}$ Solvent extracted rapeseed meal of low glucosinolate content.

${ }^{2}$ Regumaize 44 (SvG Intermol Ltd., Bootle, Merseyside, UK); declared composition (g/kg of DM) crude protein (44.0), water soluble carbohydrate $(550)$, and metabolizable energy content $(11.8 \mathrm{MJ} / \mathrm{kg}$ DM).

${ }^{3}$ Fish oil contained (g/kg, of fatty acids) C14:0 (73), C16:0 (158), C16:1 cis-9 (88), C16:4n-1 (21), C18:0 (29), C18:1 cis-9 (84), C18:1 cis-11 (30), C18:2n -6 (15), C18:4n-3 (34), C20:1 cis-9 (17), C20:5n-3 (174), C22:5n-3 (18), and C22:6n-3 (123).

${ }^{4}$ Sunflower oil contained (g/kg, of fatty acids) C16:0 (60), C18:0 (32), C18:1 cis-9 (225), and C18:2n-6 (652).

${ }^{5}$ Proprietary mineral and vitamin supplement (Dairy Direct; Bury St. Edmonds, UK) contained (g/kg) calcium (270), magnesium (60), sodium (40), phosphorus (40) zinc (5.0), manganese (4.0), copper (1.5); $(\mathrm{mg} / \mathrm{kg})$, iodine (500), cobalt (50), selenium (15); (IU/g) retinyl acetate (500), cholecalciferol (100), DL- $\alpha$-tocopheryl acetate (0.5).

${ }^{6}$ Contains 500,000 IU of DL- $\alpha$-tocopheryl acetate per kilogram.

used were licensed, regulated, and inspected by the UK Home Office under the Animals (Scientific Procedures) Act of 1986.

\section{Milk Collection and Pasteurization}

Cows were milked at 0700 and $1600 \mathrm{~h}$. Milk from all cows was collected in a refrigerated bulk tank from $1600 \mathrm{~h}$ on d 4 until $0700 \mathrm{~h}$ on $\mathrm{d} 6$ for the control and experimental feeding periods. During each experimental week, milk collected from $1600 \mathrm{~h}$ on $\mathrm{d} 4$ to $0700 \mathrm{~h}$ on d 5 was used to prepare UHT milk, and that collected from $1600 \mathrm{~h}$ on d 5 to $0700 \mathrm{~h}$ on d 6 was used for the manufacture of cheese and butters. Representative subsamples $(n=4)$ of both control and experimental milk were taken from bulk tank milk collected during the first two milkings of each feeding period and stored at $-20^{\circ} \mathrm{C}$ until analyzed for fatty acid composition.
After cooling to $4^{\circ} \mathrm{C}$ in the bulk tank, control and experimental milks were transported within $1 \mathrm{~h}$ from the end of the morning milking of all experimental cows to the pilot processing plant at the University of Reading. Milk was pasteurized at $72^{\circ} \mathrm{C}$ for $15 \mathrm{~s}$ using a continuous high-temperature, short-time plant (Junior plate heat exchanger, Invensys APV, Crawley, UK).

Milk fat, CP, and lactose content were determined with a Dairylab 2 analyzer (Foss Electric, York, UK). Near infrared detection of milk constituents was calibrated using milk samples for which reference measurements had previously been made using standard procedures (AOAC, 1990). Estimation of milk CP content by near infrared spectroscopy was based on the assumption that the ratio of true protein to nonprotein nitrogen was constant.

\section{Ultra-High-Temperature Processed Milk}

Fresh milk was homogenized and treated in an indirect UHT plant (JHE plate heat exchanger, Invensys APV, Crawley, UK) at $142^{\circ} \mathrm{C}$ for $2 \mathrm{~s}$, packaged under UV light into sterile pots (Bibby Sterilin, Stone, UK) and stored at $4^{\circ} \mathrm{C}$. Milk fat globule size was assessed by photon correlation spectroscopy using a N4 submicron particle analyzer (detection range $=1$ to $3000 \mathrm{~nm}$; Beckman Coulter, Luton, UK). Samples of milk were saponified and vitamin $\mathrm{E}$ was extracted with mixed ethers (Lumley, 1993). Quantification of vitamin E as DL- $\alpha$-tocopherol was based on HPLC and fluorescence detection (Lumley, 1993).

Representative samples of UHT control and experimental milk $(n=4)$ were collected and stored at $-20^{\circ} \mathrm{C}$ until analyzed for fatty acid composition.

\section{Butter Making}

Pasteurized milk was separated using a centrifugal separator (113 A.C.F.; R. A. Lister, Dursley, UK). The cream obtained was then standardized to a fat content of $400 \mathrm{~g} / \mathrm{kg}$, chilled, and stored overnight at $5^{\circ} \mathrm{C}$. The cream was divided into four equal amounts so that that four batches of butter could be prepared. Individual portions of cream were transferred to a sterilized butter churn (50-kg capacity; Melotte, Gascoigne, UK) and rotated slowly for $2 \mathrm{~min}$ before being vented. Thereafter, the churn was rotated at high speed and inspected every 10 min until small butter grains were formed. The buttermilk was then drained away, cold potable water $\left(4^{\circ} \mathrm{C}\right)$ was added, and the churn was rotated at low speed for $15 \mathrm{~s}$ and then drained away. Both the washing and draining stages were then repeated. Finally, salt (10 g/kg; wt/wt) was sprinkled over the sur- 
face of the butter grains and the churn was rotated at slow speed for 2 min to allow the salt and butter to consolidate. The butter was then blended with a Stefan mixer (Stefan Machinery Ltd., Middlesex, UK), packaged into $200-\mathrm{g}$ pots, and stored at $8^{\circ} \mathrm{C}$ or $-18^{\circ} \mathrm{C}$.

Butters were sampled for the determination of chemical composition between 7 and $14 \mathrm{~d}$ after manufacture and analyzed in duplicate for fat (Mojonnier method; Atherton and Newlander, 1977) and moisture content (oven drying at $105^{\circ} \mathrm{C}$ to constant weight). The vitamin $\mathrm{E}$ content of butter samples was determined by HPLC using the same procedures applied to milk.

\section{Cheese Making}

Pasteurized milk was incubated for $30 \mathrm{~min}$ at $30^{\circ} \mathrm{C}$ with a Mesophilic aromatic culture (CHR Hansen, Hungerford, UK) and stirred continuously. Thereafter, $0.03 \%$ (wt/wt) rennet (CHY-Max Plus fermentationproduced chymosin; CHR Hansen, Horsholm, Denmark) was added. Stirring was stopped after 2 min. Coagulation was monitored after $40 \mathrm{~min}$ and once firm, the curd was cut using vertical and horizontal knives. The cut curd was then stirred at $32.5^{\circ} \mathrm{C}$ until titratable acidity had risen by $0.01 \%$ (wt/wt) lactic acid (assessed by titration against $0.11 M \mathrm{NaOH}$ using phenolphthalein indicator), at which point, the whey was drained. After consolidation for 20 min, the cut curd was divided into sections approximately $12 \mathrm{~cm}$ wide, inverted, and left for $20 \mathrm{~min}$. Once the titratable acidity of the whey exceeded $0.2 \%$ (wt/wt) lactic acid, cheese sections were cut into halves every 10 to $15 \mathrm{~min}$ until the acidity reached $0.35 \%$ (wt/wt) lactic acid. The curd was milled, salted $(25 \mathrm{~g} / \mathrm{kg}$ milk), transferred into cylindrical molds ( $22.0 \mathrm{~cm}$ high and $9.2 \mathrm{~cm}$ wide, respectively) and pressed at room temperature for $24 \mathrm{~h}$. Five batches of cheese were prepared. The following day, cheeses were removed from the press, packaged under vacuum, and stored at $8^{\circ} \mathrm{C}$ for a 3 -wk maturation period. Following maturation, the cheeses were stored at either $-18^{\circ} \mathrm{C}$ or $8^{\circ} \mathrm{C}$.

Cheeses were sampled for chemical composition analysis between 7 and $14 \mathrm{~d}$ after maturation and analyzed in duplicate for fat and moisture content using the Werner-Schmid method (Egan et al., 1981) and oven drying at $105^{\circ} \mathrm{C}$ to constant weight, respectively. Samples of cheese were saponified and vitamin E was extracted and determined using the same procedures applied to samples of UHT milk.

\section{Fatty Acid Composition of Milk and Dairy Products}

Lipid in raw and UHT milk, butter, and cheese was extracted in duplicate using a mixture of diethyl ether and hexane (5:4, vol/vol) according to reference procedures (IDF 1C:1987; IDF 16C:1987; Int. Dairy Fed., Brussels, Belgium). Both lipid extracts were combined and evaporated to dryness at $60^{\circ} \mathrm{C}$ under nitrogen for $1 \mathrm{~h}$.

Extracted lipids were dissolved in hexane and methyl acetate and transesterified to fatty acid methyl esters (FAME) using freshly prepared methanolic sodium methoxide according to Christie (1982). The mixture was neutralized with oxalic acid ( $1 \mathrm{~g}$ of oxalic acid in $30 \mathrm{~mL}$ of diethyl ether), centrifuged, and dried using calcium chloride.

The FAME were separated and quantified with a gas chromatograph (3400 CX, Varian Instruments, Walnut Creek, CA) equipped with a flame-ionization detector, automatic injector, split injection port, and a $100-\mathrm{m}$ fused-silica capillary column $(0.25 \mathrm{~mm}$ i.d. $)$ coated with $0.2-\mu \mathrm{m}$ cyanopropyl polysiloxane film (CPSIL 88, Chrompack, Middelburg, The Netherlands) using hydrogen as the carrier and fuel gas according to Shingfield et al. (2003). Individual FAME of C18:1 and C18:2 fatty acids were determined under isothermal conditions. Column temperature was maintained at $160^{\circ} \mathrm{C}$ for $75 \mathrm{~min}$, increased to $240^{\circ} \mathrm{C}$ at a rate of $25^{\circ} \mathrm{C} /$ $\mathrm{min}$, and held at this temperature for $10 \mathrm{~min}$. Individual isomers of C18:1 and nonconjugated C18:2 were identified according to Shingfield et al. (2003, 2005). Isomers of CLA were identified by comparison of retention times with authentic CLA methyl ester standards (Matreya Inc., Pleasant Gap, PA, and Sigma, St. Louis, MO) using cis-9, trans-11 as a landmark isomer. Identification was further validated based on electron impact ionization spectra obtained by mass spectrometry and cross-referencing with known CLA isomeric profiles of milk samples previously analyzed by silver-ion HPLC (Shingfield et al., 2003, 2005). Under the gas-chromatography conditions used, the major CLA peak comprises unresolved trans-7,cis-9; trans-8,cis-10, and cis9 ,trans-11. For cows fed comparable rations containing fish oil and sunflower oil, trans-7,cis-9 CLA and trans8,cis-10 CLA represent proportionately (mean $\pm \mathrm{SE}$ ) $0.066 \pm 0.019$ and $0.013 \pm 0.002$ of milk fat cis-9,trans11 CLA content, respectively (Shingfield et al., 2005), and therefore the major CLA peak determined by gas chromatography was assumed to reflect changes in the predominant cis-9,trans-11 isomer.

\section{Texture Analysis}

The evaluation of the textural properties of the cheese and butter was carried out weekly, over an 8wk period, for at least 3 samples for each product using a TA-XT2i texture analyzer (Stable Micro Systems Ltd., Godalming, UK) equipped with a 5-mm-diameter 
$\mathrm{P} / 5$ cylindrical stainless steel probe. Cheese samples were cut into $3-\mathrm{cm}$ cubes after maturation and packaged under vacuumbefore being stored at either $8^{\circ} \mathrm{C}$ or $-18^{\circ} \mathrm{C}$. Butter samples in 200 -g pots were analyzed directly. Frozen samples were defrosted at $8^{\circ} \mathrm{C}$ for 24 $\mathrm{h}$ before analysis. Although butter and cheese would not normally be stored under these conditions, the aim was to test the suitability of the products for freezing and to compare the effects of extremes of temperature on the texture of the products. All samples were allowed to equilibrate to room temperature $\left(20 \pm 2{ }^{\circ} \mathrm{C}\right)$ for $30 \mathrm{~min}$ prior to testing. Testing conditions were as follows: pretest speed, $5 \mathrm{~mm} / \mathrm{s}$; test speed, $1 \mathrm{~mm} / \mathrm{s}$; posttest speed, $5 \mathrm{~mm} / \mathrm{s}$; distance, $20 \mathrm{~mm}$.

\section{Sensory Evaluation}

Triangle tests were conducted on UHT milk ( $1 \mathrm{wk}$ after processing), butter ( $2 \mathrm{wk}$ after manufacture), and cheese ( 1 wk after maturation) by a panel $(n=20)$ of consumer volunteers (Meilgaard et al., 1999). Each volunteer received 3 randomly coded samples, 2 of which were the same and one that was different. Panelists were asked to select the odd sample from each set and comment on the presence of off flavors. In cases where the odd sample could not be identified, consumers were forced to make a choice.

Organoleptic assessment of cheese, butter, and UHT milk was performed by an experienced taste panel ( $\mathrm{n}=$ 5). Each taste panel member assessed each product using a 10-point line scale, with 1 being the lowest and 10 representing the highest intensity (Meilgaard et al., 1999). Cheese was assessed for the following attributes: hardness, based on the resistance manifested by the cheese sample when it was placed between the jaws and pressed lightly by the teeth; crumbliness, based on the ability of the cheese sample to be broken into numerous pieces when starting mastication; aroma, based on the intensity of the stimulation perceived when the cheese sample approached the nose; flavor, based on the intensity of the stimulation perceived when the cheese sample was chewed for a few seconds while breathing out; overall impression, based on the final impression after each of the sensory characteristics had been assessed. Samples of butter were assessed for melt rate in the mouth, based on the time taken for the butter to melt on the tongue; coating, based on residual coating in the mouth immediately after swallowing; flavor, based on the intensity of the stimulation perceived when the butter first entered the mouth; overall impression, based on the final impression once all other sensory characteristics of the butter had been noted.
Table 2. Scaling magnitudes used for the sensory evaluation of experimental cheese and butter.

\begin{tabular}{lll}
\hline Attribute & 1 & 10 \\
\hline Hardness & Soft & Hard \\
Crumbliness & Nil & Extreme \\
Creaminess & Nil & Extreme \\
Aroma & Nil & Extreme \\
Melt rate & Nil & Extreme \\
Flavor & Nil & Extreme \\
Melt rate & Slow & Fast \\
Coating & Nil & Extreme \\
Overall impression & Unacceptable & Excellent product \\
\hline
\end{tabular}

Samples of UHT milk were assessed for creaminess, based on the intensity of the stimulation perceived when the milk first entered the mouth; coating, based on the residual coating in the mouth immediately after swallowing; flavor, based on the intensity of the stimulation perceived when the milk first entered the mouth; aroma, based on the intensity of the stimulation perceived when the milk sample approached the nose; overall impression, based on the final impression after all individual sensory characteristics had been assessed. The scaling magnitudes for each of the sensory characteristics determined are shown in Table 2.

\section{Statistical Analyses}

Pairwise $t$-tests were used to assess the significance $(P<0.05)$ of differences between the fatty acid composition and chemical content of raw milk and dairy products produced from the control and FSO diet using the GLM procedure of SAS (SAS Inst., Inc., Cary, NC). Measurements of cheese texture and organoleptic scores of UHT milk and cheese were subjected to ANOVA for repeated measures using the mixed linear model procedure of SAS. For textural measurements, the statistical model included the effects of storage time, storage temperature, treatment, and their interaction and used an autoregressive order one covariance structure fitted on the basis of Akaike Information and Schwarz Bayesian model-fit criteria. Least square means are presented with differences between treatments being considered significant at $P<0.05$. Data from the sensory triangle tests were analyzed using the table for "Critical Number (Minimum) of Correct Answers," and significance was declared at $P$ $<0.01$.

\section{RESULTS AND DISCUSSION}

This study was conducted to evaluate the sensory, physical, and chemical attributes of UHT milk, cheese, and butter manufactured from milk with an enhanced 
content of $c i s-9$,trans-11 CLA. A recent human supplementation study demonstrated effects of cis-9,trans11 CLA on immune function and blood lipids at a dose of approximately $1.2 \mathrm{~g} / \mathrm{d}$ and above (Tricon et al., 2004a,b). We therefore wished to produce milk, butter, and cheese, which, at a reasonable level of consumption, could be used to test whether delivering cis9, trans-11 CLA through naturally modified dairy products would have similar effects on human health as encapsulated cis-9,trans-11 CLA, without compromising the acceptability and processing characteristics of the milk.

\section{Composition of Raw and Ultra-High- Temperature Processed Milk}

Inclusion of fish oil and sunflower oil in the diet resulted in marked changes in the fatty acid composition of milk (Table 3). Concentrations of total and cis9,trans-11 CLA were approximately ninefold higher in milk from cows fed the FSO diet compared with the control. The increases in milk fat CLA content were achieved by supplementing a basal corn silage-based ration with a mixture of fish oil and sunflower oil. Earlier studies showed that fish oil is more effective than plant oils for enhancing milk fat CLA content (Offer et al., 1999; Chouinard et al., 2001), and these responses can be further increased when fish oil is fed in combination with feeds containing C18:2 (n-6) (AbuGhazaleh et al., 2002, 2003; Whitlock et al., 2002). In an attempt to optimize milk fat cis-9,trans-11 CLA enrichment (i.e., to increase cis-9,trans-11 CLA to a level at which consumption could produce effects on immune function and blood lipids in humans, as shown in Tricon et al., 2004a,b), lipid supplements were incorporated into a predominantly forage-based diet (Shingfield et al., 2005). Furthermore, milk was collected between d 5 and 7 of lipid supplementation following reports that CLA concentrations in milk from cows fed diets containing sunflower oil (Bauman et al., 2000), soybean oil (Dhiman et al., 2000), or combinations of fishmeal and extruded soybeans (Whitlock et al., 2002) decline over time. In some cases, milk fat CLA responses to soybean meal in grazing cows (Loor et al., 2002) or to combinations of fishmeal and extruded soybeans in cows fed corn silage-based diets (Abu-Ghazaleh et al., 2004) were reported to increase with time on diet. However, before the start of this experiment, a pilot study using smaller numbers of cows in mid-lactation offered the same diets was conducted to identify the duration of supplementation required to optimize milk fat cis-9,trans-11 CLA responses to fish oil and sunflower oil. Under these conditions, cis-9,trans-11 CLA concentrations in milk fat in response to the FSO diet were highest between $\mathrm{d} 3$ and 7 (K. S. Shingfield, A. K. Jones, B. Lupoli, and D. E. Beever, unpublished data, 2005).

Enrichment in milk fat CLA content was accompanied by alterations in the concentrations of other fatty acids, which included a decrease in C16:0, C18:0, total cis C18:1, and C18:2 (n-6), and an increase in transC18:1, trans-C18:2, total C18:1, C20:5 (n-3), C22:6 (n3 ) and total n-3 PUFA content (Table 3). Almost $80 \%$ of the total milk fat trans $\mathrm{C} 18: 1$ response to the FSO diet was due to an increase in trans-11 C18:1. Thus, consumption of the CLA-enriched milk and dairy products produced in this study would not simply increase CLA supply from the diet but also alter the intakes of other fatty acids. The increased levels of trans-fatty acids could have a detrimental influence on human health (Zock and Katan, 1992). On the other hand, the reduced saturated fatty acid content could act in concert with cis-9,trans-11 CLA in reducing the ratio of LDL:HDL and of total cholesterol:HDL. There is clearly a need to determine the impact on human health of modified dairy products with this type of fatty acid profile and to determine whether the presence of trans-11 C18:1 (vaccenic acid) is indeed of concern as previous studies have only tested the effects of elaidic acid (trans-9 C18:1) (Zock and Katan, 1992). If the presence of trans-11 C18:1 in CLA-enriched dairy products is demonstrated to have a detrimental effect on human health, alternative strategies would need to be devised to enrich milk with cis-9,trans-11 CLA without the associated increase in trans fatty acids.

The study by Tricon et al. (2004a,b) would suggest that an intake of $1.5 \mathrm{~g} / \mathrm{d}$ of cis-9,trans-11 CLA would be sufficient to observe effects on immune function and blood lipids (disregarding any potential effects of trans-fatty acids). If this level of cis-9,trans-11 CLA intake is to be achieved without dramatically increasing the consumption of dairy products, a high level of cis-9,trans-11 CLA enrichment of milk is required, as in the current study, but this may only be achieved transiently and may have a negative impact on the health of the animal. Lower levels of enrichment of cow's milk with cis-9,trans-11 CLA ( $\sim 3.5$-fold) following feeding of fish meal and extruded soybean have, on the other hand, been shown to be maintained for an extended period of time (Abu-Ghazaleh et al., 2004). However, it is unclear whether consumption of cis9,trans-11 CLA by humans at the levels that could be provided by dairy products made from milk with this level of enrichment would have any biological effects. It is notable that the only study published to date which examines the effects of CLA-enriched dairy products on human health employed milk-based drinks to which synthetic CLA isomers (cis-9,trans-11 
Table 3. Fatty acid composition (g/100 g, of total fatty acids) of raw milk from cows fed corn silage-based diets containing 0 (control) or $45 \mathrm{~g} / \mathrm{kg}$ of a mixture (1:2, wt/wt) of fish oil and sunflower oil (FSO), where values are the mean of $\mathrm{n}=4$ determinations. ${ }^{1}$

\begin{tabular}{|c|c|c|c|}
\hline \multirow[b]{2}{*}{ Item } & \multicolumn{2}{|c|}{ Diet } & \multirow{2}{*}{$\begin{array}{l}\text { Poolec } \\
\text { SEM }\end{array}$} \\
\hline & Control & FSO & \\
\hline $\mathrm{C} 4: 0$ & 4.18 & 4.04 & 0.058 \\
\hline C6:0 & 2.02 & 1.96 & 0.052 \\
\hline $\mathrm{C} 8: 0$ & 1.11 & 1.10 & 0.038 \\
\hline C10:0 & 2.26 & 2.19 & 0.084 \\
\hline $\mathrm{C} 12: 0$ & 2.68 & 2.48 & 0.085 \\
\hline C14:0 & 9.56 & 9.09 & 0.162 \\
\hline $\mathrm{C} 14: 0$ cis -9 & 0.81 & $0.59 *$ & 0.010 \\
\hline C15:0 & 0.94 & $0.85^{*}$ & 0.011 \\
\hline $\mathrm{C} 15: 0$ iso & 0.20 & $0.16^{*}$ & 0.003 \\
\hline C15:0 ante-iso & 0.37 & $0.29 *$ & 0.005 \\
\hline C16:0 & 30.52 & $25.41 *$ & 0.107 \\
\hline $\mathrm{C} 16: 1$ cis-9 & 2.26 & $1.62 *$ & 0.012 \\
\hline C17:0 & 0.77 & $0.56^{*}$ & 0.006 \\
\hline $\mathrm{C} 17: 0$ iso & 0.41 & $0.80 *$ & 0.004 \\
\hline C17:0 ante-iso & 0.24 & $0.15^{*}$ & 0.003 \\
\hline $\mathrm{C} 18: 0$ & 9.96 & $4.20 *$ & 0.098 \\
\hline $\mathrm{C} 18: 1$ cis -9 & 21.80 & $10.85^{*}$ & 0.205 \\
\hline C18:1 cis-11 & 0.84 & $1.10^{*}$ & 0.011 \\
\hline C18:1 cis-12 & 0.18 & $0.22 *$ & 0.001 \\
\hline C18:1 cis-13 & 0.15 & 0.15 & 0.007 \\
\hline C18:1 cis-15 & 0.02 & $0.07 *$ & 0.008 \\
\hline C18:1 cis-16 & 0.06 & $0.09 *$ & 0.004 \\
\hline C18:1 trans -4 & 0.02 & $0.07^{*}$ & 0.004 \\
\hline $\mathrm{C} 18: 1$ trans -5 & 0.02 & $0.08 *$ & 0.002 \\
\hline C18:1 trans $-6,-7,-8$ & 0.21 & $0.74 *$ & 0.004 \\
\hline C18:1 trans -9 & 0.20 & $0.72 *$ & 0.007 \\
\hline C18:1 trans -10 & 0.22 & $1.27 *$ & 0.072 \\
\hline C18:1 trans -11 & 1.03 & $14.36^{*}$ & 0.057 \\
\hline C18:1 trans-12 & 0.23 & $1.04 *$ & 0.007 \\
\hline C18:1 trans $-13,-14$ & 0.39 & $1.07 *$ & 0.012 \\
\hline C18:1 trans -15 & 0.15 & $0.29 *$ & 0.006 \\
\hline C18:1 trans -16 & 0.22 & $0.16^{*}$ & 0.007 \\
\hline $\mathrm{C} 18: 1$ cis total & 23.05 & $12.48^{*}$ & 0.231 \\
\hline C18:1 trans total & 2.69 & $19.58^{*}$ & 0.137 \\
\hline C18:1 total & 25.74 & $32.06^{*}$ & 0.361 \\
\hline C18:2 cis- 9, cis-12 & 1.87 & $1.50 *$ & 0.030 \\
\hline C18:2 cis-9, trans -12 & 0.06 & 0.08 & 0.006 \\
\hline C18:2 cis-9, trans -13 & 0.13 & $0.22 *$ & 0.001 \\
\hline C18:2 trans- 9, cis -12 & 0.01 & $0.16^{*}$ & 0.001 \\
\hline C18:2 trans -11, cis-15 & 0.08 & $0.48^{*}$ & 0.009 \\
\hline $\mathrm{C} 18: 2$ trans -9, trans -12 & 0.00 & 0.02 & 0.008 \\
\hline $\mathrm{C} 18: 2$ total $^{2}$ & 2.38 & $2.72^{*}$ & 0.051 \\
\hline cis-9, trans-11 CLA & 0.49 & $4.46^{*}$ & 0.044 \\
\hline trans-9, cis-11 CLA & 0.00 & $0.04 *$ & 0.005 \\
\hline trans-10, cis-12 CLA & 0.00 & 0.02 & 0.006 \\
\hline trans-11, cis-13 CLA & 0.02 & 0.02 & 0.003 \\
\hline trans-11, trans-13 CLA & 0.02 & 0.03 & 0.005 \\
\hline trans, trans $\mathrm{CLA}^{3}$ & 0.00 & $0.05^{*}$ & 0.004 \\
\hline CLA total & 0.54 & $4.68^{*}$ & 0.045 \\
\hline C18:3 (n-3) & 0.28 & $0.19 *$ & 0.010 \\
\hline C18:3 (n-6) & 0.05 & 0.03 & 0.007 \\
\hline C18:4 (n-3) & 0.00 & $0.02 *$ & 0.007 \\
\hline $\mathrm{C} 20: 0$ & 0.16 & 0.14 & 0.007 \\
\hline $\mathrm{C} 20: 1$ cis -11 & 0.08 & $0.24 *$ & 0.009 \\
\hline C20:2 (n-3) & 0.04 & 0.03 & 0.010 \\
\hline $\mathrm{C} 20: 2(\mathrm{n}-6)$ & 0.04 & 0.04 & 0.010 \\
\hline C20:3 (n-3) & 0.00 & $0.18^{*}$ & 0.006 \\
\hline $\mathrm{C} 20: 3(\mathrm{n}-6)$ & 0.11 & $0.14^{*}$ & 0.005 \\
\hline C20:4 (n-3) & 0.03 & $0.21^{*}$ & 0.006 \\
\hline C20:4 (n-6) & 0.17 & 0.15 & 0.007 \\
\hline C20:5 (n-3) & 0.05 & $0.12 *$ & 0.003 \\
\hline $\mathrm{C} 22: 0$ & 0.05 & $0.10^{*}$ & 0.003 \\
\hline
\end{tabular}

Table 3 (Continued). Fatty acid composition (g/100 g, of total fatty acids) of raw milk from cows fed corn silage-based diets containing 0 (control) or $45 \mathrm{~g} / \mathrm{kg}$ of a mixture (1:2, wt/wt) of fish oil and sunflower oil (FSO), where values are the mean of $n=4$ determinations. ${ }^{1}$

\begin{tabular}{lccc}
\hline & \multicolumn{2}{c}{ Diet } & \\
\cline { 2 - 3 } Item & Control & FSO & SEM \\
\hline C22:4 (n-3) & 0.00 & $0.29^{*}$ & 0.022 \\
C22:5 (n-3) & 0.10 & $0.23^{*}$ & 0.007 \\
C22:5 (n-6) & 0.00 & 0.02 & 0.007 \\
C22:6 (n-3) & 0.00 & $0.10^{*}$ & 0.005 \\
C24:0 & 0.02 & 0.03 & 0.002 \\
Other & 1.72 & $2.61^{*}$ & 0.067 \\
Total $\leq$ C14 & 25.66 & 22.21 & 0.499 \\
Total saturates & 68.42 & $55.76^{*}$ & 0.461 \\
Total MUFA & 27.86 & $35.11^{*}$ & 0.331 \\
Total PUFA & 3.65 & $9.02^{*}$ & 0.158 \\
Total (n-3) PUFA & 0.51 & $1.32^{*}$ & 0.036 \\
Total (n-6) PUFA & 2.14 & 2.08 & 0.073 \\
\hline
\end{tabular}

${ }^{1} \mathrm{CLA}=$ Conjugated linoleic acid, $\mathrm{MUFA}=$ monounsaturated fatty acids, PUFA = polyunsaturated fatty acids.

${ }^{2} \mathrm{Sum}$ of C18:2 excluding isomers of CLA.

${ }^{3}$ Mixture of unresolved trans-7, trans-9 CLA, trans-8, trans-10 CLA, trans-9, trans-11 CLA, and trans-10, trans-12 CLA.

${ }^{4}$ Refers to the sum of other identified fatty acids.

*Significant $(P<0.05)$ difference from control mean.

and trans-10,cis-12) were added post-production (Malpuech-Brugere et al., 2004).

In addition to changes in milk fatty acid composition, milk from cows fed the FSO diet had a lower protein

Table 4. Chemical composition of UHT processed milk, butter, and cheese prepared using milk from cows fed the control or experimental (Expt) diet.

\begin{tabular}{lccc}
\hline & \multicolumn{2}{c}{ Diet } & \\
\cline { 2 - 3 } Item & Control & Expt & Pooled \\
SEM
\end{tabular}

${ }^{1}$ Values are the mean of $\mathrm{n}=4$ determinations.

${ }^{2}$ Values are the mean of $\mathrm{n}=3$ determinations.

${ }^{3}$ Values are the mean of $\mathrm{n}=8$ determinations.

${ }^{4}$ Values are the mean of $\mathrm{n}=5$ determinations.

*Significant $(P<0.05)$ difference from control mean. 
Table 5. Fatty acid composition of UHT processed milk, butter, and Caerphilly cheese prepared using milk from cows fed the control or experimental (Expt) diet (g/100 g, of fatty acids), where values are the mean of $\mathrm{n}=4$ determinations. ${ }^{1}$

\begin{tabular}{|c|c|c|c|c|c|c|c|c|c|}
\hline \multirow[b]{2}{*}{ Product } & \multicolumn{3}{|c|}{ UHT milk } & \multicolumn{3}{|c|}{ Butter } & \multicolumn{3}{|c|}{ Cheese } \\
\hline & Control & Expt & $\begin{array}{l}\text { Pooled } \\
\text { SEM }\end{array}$ & Control & Expt & $\begin{array}{l}\text { Pooled } \\
\text { SEM }\end{array}$ & Control & Expt & $\begin{array}{l}\text { Pooled } \\
\text { SEM }\end{array}$ \\
\hline C4:0 & 4.23 & $3.90^{*}$ & 0.055 & 5.09 & 4.70 & 0.091 & 4.21 & $3.88 *$ & 0.042 \\
\hline $\mathrm{C} 6: 0$ & 2.24 & $1.97 *$ & 0.053 & 2.56 & $2.36^{*}$ & 0.043 & 2.73 & $1.95^{*}$ & 0.077 \\
\hline $\mathrm{C} 8: 0$ & 1.30 & $1.11^{*}$ & 0.040 & 1.42 & 1.35 & 0.026 & 1.51 & $1.15^{*}$ & 0.046 \\
\hline C10:0 & 2.70 & $2.26^{*}$ & 0.090 & 2.85 & 2.69 & 0.044 & 3.05 & $2.33^{*}$ & 0.082 \\
\hline $\mathrm{C} 12: 0$ & 3.11 & $2.54 *$ & 0.091 & 3.19 & $2.92 *$ & 0.041 & 3.29 & $2.58^{*}$ & 0.053 \\
\hline C14:0 & 10.61 & $9.34 *$ & 0.171 & 10.91 & $10.25^{*}$ & 0.094 & 10.62 & $9.30 *$ & 0.085 \\
\hline C14:0 cis-9 & 0.87 & $0.65^{*}$ & 0.011 & 0.90 & $0.64 *$ & 0.008 & 0.87 & $0.59 *$ & 0.005 \\
\hline C15:0 & 1.03 & $0.91 *$ & 0.011 & 1.02 & $0.92 *$ & 0.006 & 0.97 & $0.88^{*}$ & 0.005 \\
\hline $\mathrm{C} 15: 0$ iso & 0.21 & $0.15^{*}$ & 0.003 & 0.21 & $0.17 *$ & 0.003 & 0.21 & $0.16^{*}$ & 0.004 \\
\hline $\mathrm{C} 15: 0$ ante-iso & 0.40 & $0.29 *$ & 0.005 & 0.40 & $0.31 *$ & 0.004 & 0.39 & $0.29 *$ & 0.002 \\
\hline $\mathrm{C} 16: 0$ & 30.76 & $26.31^{*}$ & 0.110 & 30.50 & $26.00^{*}$ & 0.072 & 29.58 & $25.71^{*}$ & 0.112 \\
\hline $\mathrm{C} 16: 1 \mathrm{cis}-9$ & 2.28 & $1.69 *$ & 0.012 & 2.13 & $1.53^{*}$ & 0.005 & 2.06 & $1.64^{*}$ & 0.006 \\
\hline C17:0 & 0.77 & $0.56^{*}$ & 0.006 & 0.74 & $0.54^{*}$ & 0.003 & 0.73 & $0.56^{*}$ & 0.004 \\
\hline $\mathrm{C} 17: 0$ iso & 0.41 & $0.82 *$ & 0.004 & 0.42 & $0.88^{*}$ & 0.003 & 0.41 & $0.88^{*}$ & 0.003 \\
\hline $\mathrm{C} 17: 0$ ante-iso & 0.24 & $0.19 *$ & 0.004 & 0.22 & $0.17 *$ & 0.002 & 0.20 & 0.18 & 0.005 \\
\hline C18:0 & 9.34 & $4.14^{*}$ & 0.094 & 8.95 & $3.85^{*}$ & 0.042 & 9.16 & $4.14^{*}$ & 0.075 \\
\hline C18:1 cis-9 & 20.26 & $10.76^{*}$ & 0.197 & 19.73 & $9.88^{*}$ & 0.146 & 20.33 & $10.43^{*}$ & 0.124 \\
\hline C18:1 cis-11 & 0.77 & $1.11 *$ & 0.011 & 0.74 & $1.02 *$ & 0.007 & 0.76 & $1.09 *$ & 0.008 \\
\hline C18:1 cis-12 & 0.15 & $0.22 *$ & 0.001 & 0.15 & $0.18^{*}$ & 0.001 & 0.15 & $0.21 *$ & 0.002 \\
\hline C18:1 cis-13 & 0.13 & 0.15 & 0.006 & 0.11 & $0.13^{*}$ & 0.002 & 0.12 & $0.14^{*}$ & 0.001 \\
\hline C18:1 cis-15 & 0.03 & 0.06 & 0.009 & 0.02 & $0.07 *$ & 0.002 & 0.02 & $0.08 *$ & 0.001 \\
\hline C18:1 cis- 16 & 0.05 & $0.09 *$ & 0.004 & 0.04 & $0.09 *$ & 0.005 & 0.05 & $0.10 *$ & 0.002 \\
\hline $\mathrm{C} 18: 1$ trans -4 & 0.02 & $0.06^{*}$ & 0.003 & 0.01 & $0.06^{*}$ & 0.001 & 0.01 & $0.07 *$ & 0.001 \\
\hline $\mathrm{C} 18: 1$ trans -5 & 0.02 & $0.07 *$ & 0.002 & 0.01 & $0.06^{*}$ & 0.001 & 0.01 & $0.07 *$ & 0.002 \\
\hline C18:1 trans $-6,-7,-8$ & 0.20 & $0.73^{*}$ & 0.004 & 0.21 & $0.74^{*}$ & 0.015 & 0.21 & $0.73 *$ & 0.005 \\
\hline $\mathrm{C} 18: 1$ trans -9 & 0.19 & $0.73^{*}$ & 0.007 & 0.17 & $0.64 *$ & 0.028 & 0.20 & $0.71 *$ & 0.004 \\
\hline C18:1 trans -10 & 0.21 & $0.94^{*}$ & 0.054 & 0.24 & $1.39 *$ & 0.118 & 0.20 & $1.12 *$ & 0.017 \\
\hline $\mathrm{C} 18: 1$ trans -11 & 1.00 & $14.25^{*}$ & 0.056 & 0.90 & $13.70^{*}$ & 0.051 & 0.97 & $15.19 *$ & 0.096 \\
\hline C18:1 trans -12 & 0.22 & $1.02 *$ & 0.007 & 0.21 & $1.12^{*}$ & 0.005 & 0.23 & $1.06 *$ & 0.006 \\
\hline C18:1 trans $-13,-14$ & 0.32 & $1.06^{*}$ & 0.010 & 0.25 & $0.92 *$ & 0.013 & 0.34 & $0.94 *$ & 0.018 \\
\hline C18:1 trans -15 & 0.13 & $0.29^{*}$ & 0.006 & 0.10 & $0.15^{*}$ & 0.007 & 0.11 & $0.26^{*}$ & 0.006 \\
\hline C18:1 trans -16 & 0.20 & $0.16^{*}$ & 0.007 & 0.19 & $0.16^{*}$ & 0.003 & 0.21 & $0.17 *$ & 0.003 \\
\hline C18:1 cis total & 21.39 & $12.39^{*}$ & 0.220 & 20.80 & $11.37^{*}$ & 0.152 & 21.43 & $12.05^{*}$ & 0.133 \\
\hline C18:1 trans total & 2.50 & $19.31^{*}$ & 0.134 & 2.29 & $18.65^{*}$ & 0.156 & 2.50 & $20.31 *$ & 0.100 \\
\hline C18:1 total & 23.89 & $31.70^{*}$ & 0.346 & 23.09 & $30.01^{*}$ & 0.179 & 23.93 & $32.36^{*}$ & 0.229 \\
\hline $\mathrm{C} 18: 2$ cis- 9, cis- 12 & 1.71 & $1.53^{*}$ & 0.029 & 1.62 & $1.35^{*}$ & 0.013 & 1.59 & $1.44^{*}$ & 0.011 \\
\hline C18:2 cis-9, trans -12 & 0.06 & 0.07 & 0.006 & 0.07 & 0.04 & 0.013 & 0.07 & 0.07 & 0.002 \\
\hline $\mathrm{C} 18: 2$ cis- 9, trans -13 & 0.12 & $0.23^{*}$ & 0.001 & 0.13 & $0.22 *$ & 0.003 & 0.12 & $0.24^{*}$ & 0.001 \\
\hline $\mathrm{C} 18: 2$ trans -9, cis -12 & 0.01 & $0.16^{*}$ & 0.001 & 0.03 & $0.15^{*}$ & 0.006 & 0.02 & $0.17 *$ & 0.001 \\
\hline $\mathrm{C} 18: 2$ trans-11, cis-15 & 0.08 & $0.45^{*}$ & 0.009 & 0.08 & $0.45^{*}$ & 0.003 & 0.08 & $0.47^{*}$ & 0.002 \\
\hline $\mathrm{C} 18: 2$ trans -9, trans -12 & 0.00 & 0.01 & 0.006 & 0.01 & $0.04 *$ & 0.002 & 0.00 & $0.04 *$ & 0.002 \\
\hline $\mathrm{C} 18: 2$ total $^{2}$ & 2.17 & $2.69 *$ & 0.050 & 2.11 & $2.49 *$ & 0.025 & 2.09 & $2.68^{*}$ & 0.012 \\
\hline cis-9, trans-11 CLA & 0.49 & $4.45^{*}$ & 0.044 & 0.46 & $4.05^{*}$ & 0.022 & 0.44 & $4.48^{*}$ & 0.033 \\
\hline trans -9 , cis-11 CLA & 0.00 & $0.03 *$ & 0.005 & 0.01 & $0.04 *$ & 0.001 & 0.01 & $0.04 *$ & 0.002 \\
\hline trans-10, cis-12 CLA & 0.00 & 0.02 & 0.008 & 0.01 & $0.07 *$ & 0.002 & 0.00 & $0.06^{*}$ & 0.004 \\
\hline trans-11, cis-13 CLA & 0.02 & 0.02 & 0.003 & 0.02 & $0.03^{*}$ & 0.002 & 0.02 & $0.03^{*}$ & 0.001 \\
\hline trans -11 , trans-13 CLA & 0.03 & 0.03 & 0.005 & 0.02 & $0.03^{*}$ & 0.001 & 0.02 & $0.03^{*}$ & 0.002 \\
\hline trans, trans CLA $^{3}$ & 0.00 & $0.05^{*}$ & 0.004 & 0.01 & $0.04 *$ & 0.002 & 0.03 & $0.05^{*}$ & 0.002 \\
\hline CLA total & 0.54 & $4.67 *$ & 0.045 & 0.53 & $4.34^{*}$ & 0.031 & 0.52 & $4.80^{*}$ & 0.036 \\
\hline C18:3 (n-3) & 0.28 & $0.18^{*}$ & 0.010 & 0.26 & $0.17^{*}$ & 0.003 & 0.27 & $0.18^{*}$ & 0.004 \\
\hline C18:3 (n-6) & 0.06 & 0.03 & 0.007 & 0.03 & $0.01 *$ & 0.001 & 0.03 & $0.02 *$ & 0.001 \\
\hline C18:4 (n-3) & 0.00 & 0.01 & 0.005 & 0.00 & $0.02^{*}$ & 0.001 & 0.00 & $0.02^{*}$ & 0.002 \\
\hline C20:0 & 0.13 & 0.12 & 0.006 & 0.13 & 0.12 & 0.003 & 0.14 & 0.14 & 0.004 \\
\hline C20:1 cis-11 & 0.07 & $0.24 *$ & 0.008 & 0.05 & $0.20 *$ & 0.005 & 0.07 & $0.22 *$ & 0.003 \\
\hline C20:2 (n-3) & 0.02 & 0.03 & 0.004 & 0.03 & 0.03 & 0.002 & 0.02 & $0.05^{*}$ & 0.002 \\
\hline C20:2 (n-6) & 0.04 & 0.04 & 0.010 & 0.02 & $0.04 *$ & 0.001 & 0.03 & 0.02 & 0.002 \\
\hline C20:3 (n-3) & 0.01 & $0.17 *$ & 0.007 & 0.00 & $0.13^{*}$ & 0.001 & 0.00 & $0.17 *$ & 0.003 \\
\hline C20:3 (n-6) & 0.09 & $0.14^{*}$ & 0.004 & 0.08 & $0.11 *$ & 0.001 & 0.08 & $0.13^{*}$ & 0.003 \\
\hline C20:4 (n-3) & 0.03 & $0.22 *$ & 0.006 & 0.02 & $0.20 *$ & 0.002 & 0.02 & $0.22^{*}$ & 0.007 \\
\hline C20:4 (n-6) & 0.17 & 0.16 & 0.007 & 0.13 & 0.12 & 0.002 & 0.13 & 0.13 & 0.003 \\
\hline C20:5 (n-3) & 0.05 & $0.10 *$ & 0.003 & 0.04 & $0.10 *$ & 0.001 & 0.04 & $0.10^{*}$ & 0.002 \\
\hline $\mathrm{C} 22: 0$ & 0.05 & $0.09 *$ & 0.003 & 0.04 & $0.07^{*}$ & 0.001 & 0.05 & $0.09 *$ & 0.002 \\
\hline
\end{tabular}


Table 5 (Continued). Fatty acid composition of UHT processed milk, butter, and Caerphilly cheese prepared using milk from cows fed the control or experimental (Expt) diet (g/100 g, of fatty acids), where values are the mean of $\mathrm{n}=4$ determinations. ${ }^{1}$

\begin{tabular}{|c|c|c|c|c|c|c|c|c|c|}
\hline \multirow[b]{2}{*}{ Product } & \multicolumn{3}{|c|}{ UHT milk } & \multicolumn{3}{|c|}{ Butter } & \multicolumn{3}{|c|}{ Cheese } \\
\hline & Control & Expt & $\begin{array}{l}\text { Pooled } \\
\text { SEM }\end{array}$ & Control & Expt & $\begin{array}{l}\text { Pooled } \\
\text { SEM }\end{array}$ & Control & Expt & $\begin{array}{l}\text { Pooled } \\
\text { SEM }\end{array}$ \\
\hline $\mathrm{C} 22: 4(\mathrm{n}-3)$ & 0.00 & $0.24^{*}$ & 0.018 & 0.00 & $0.17^{*}$ & 0.001 & 0.00 & $0.22 *$ & 0.014 \\
\hline $\mathrm{C} 22: 5(\mathrm{n}-3)$ & 0.09 & $0.22 *$ & 0.006 & 0.07 & $0.17^{*}$ & 0.003 & 0.08 & $0.20 *$ & 0.003 \\
\hline C22:5 (n-6) & 0.00 & 0.02 & 0.005 & 0.00 & $0.02^{*}$ & 0.001 & 0.00 & $0.02 *$ & 0.002 \\
\hline C22:6 (n-3) & 0.00 & $0.10^{*}$ & 0.006 & 0.01 & $0.07 *$ & 0.002 & 0.01 & $0.08^{*}$ & 0.003 \\
\hline $\mathrm{C} 24: 0$ & 0.04 & $0.03^{*}$ & 0.002 & 0.03 & 0.03 & 0.001 & 0.03 & 0.03 & 0.001 \\
\hline Other ${ }^{4}$ & 1.70 & 1.82 & 0.050 & 1.39 & $2.00 *$ & 0.020 & 1.72 & $1.96^{*}$ & 0.007 \\
\hline Total $\leq \mathrm{C} 14$ & 25.73 & $22.28 *$ & 0.520 & 27.61 & $25.49 *$ & 0.259 & 28.06 & $21.99 *$ & 0.488 \\
\hline Total saturates & 68.72 & $55.87 *$ & 0.462 & 69.87 & $58.57^{*}$ & 0.244 & 69.47 & $55.25^{*}$ & 0.300 \\
\hline Total MUFA & 27.66 & $35.02 *$ & 0.333 & 26.73 & $33.12^{*}$ & 0.184 & 27.16 & $35.56^{*}$ & 0.240 \\
\hline Total PUFA & 3.53 & $8.97 *$ & 0.154 & 3.32 & $8.13^{*}$ & 0.060 & 3.29 & $9.00 *$ & 0.065 \\
\hline Total $(n-3)$ PUFA & 0.49 & $1.27^{*}$ & 0.034 & 0.44 & $1.04^{*}$ & 0.012 & 0.45 & $1.21^{*}$ & 0.011 \\
\hline Total $(n-6)$ PUFA & 2.10 & 2.09 & 0.069 & 1.91 & $1.78^{*}$ & 0.014 & 1.89 & 1.95 & 0.026 \\
\hline
\end{tabular}

content, but higher fat content compared with the control (Table 4). The experimental UHT milk had a lower protein content $(P<0.05)$, a higher fat content $(P<$ $0.05)$ and a smaller mean milk fat globule size compared with the control UHT milk (Table 4). Fatty acid composition changes in UHT milk paralleled those observed in raw milk (Table 5). Concentrations of lactose and vitamin $\mathrm{E}$ also were comparable between the control and experimental UHT processed milks. Excessive amounts of unsaturated oils in the diet are known to reduce fiber digestion in the rumen (Jenkins, 1993) and often cause a reduction in DMI, milk yield, and milk protein content (Wu and Huber, 1994; Chilliard et al., 2001; Lock and Shingfield, 2004). Feeding diets containing fish oil and C18:2 (n-6) rich oilseeds (Whitlock et al., 2002; Abu-Ghazaleh et al., 2003) or fish meal and extruded soybeans (Abu-Ghazaleh et al., 2003) have been shown to lower milk protein concentrations. Dry matter intakes were not measured in this experiment, but energy intake is considered the major nutritional factor affecting milk protein concentrations (Coulon and Remond, 1991; Lock and Shingfield, 2004). It is possible that the decreases in milk protein content due to feeding the FSO diet were related to a reduction in DMI. However, the main aim of this experiment was to produce CLA enriched milk and dairy products to test in human intervention studies, rather than provide a rigorous evaluation of the effects of fish oil and sunflower oil in the diet on animal performance. The higher fat content in the experimen- tal milk was unexpected, since fish oil, and to a lesser extent, plant oils, typically decrease both milk fat and protein concentrations (Chilliard et al., 2001; Lock and Shingfield, 2004). It is possible that the higher than expected fat content of milk was a consequence of the relatively short duration of lipid supplementation used to produce CLA enriched milk, but may also be explained by the limited number of milk samples collected during this period.

\section{Cheese and Butter Making Properties and Characteristics}

There was no difference in the amount of moisture, protein, or vitamin $\mathrm{E}$ between the cheeses, but the fat content of the experimental cheese was lower than the control, even though the experimental milk had a lower protein content and a higher fat content (Table 4). This suggests that there were higher losses of fat in whey during the manufacture of experimental vs. control cheese, but the reasons for these differences remain unclear.

The yield of cheese produced from the experimental CLA-enriched milk was numerically lower, but not significantly different from the control (Table 4). The yield of butter from the experimental milk was marginally, but not significantly, lower than from the control (Table 4). However, experimental butter contained higher amounts of moisture and vitamin $\mathrm{E}$, and lower concentrations of fat compared with the control (Table 4). 
Table 6. Fatty acid content (g/kg, of product) of UHT processed milk, butter, and Caerphilly cheese prepared using milk from cows fed the control or experimental (Expt) diet, where values are based on the mean of $\mathrm{n}=4$ determinations. ${ }^{1}$

\begin{tabular}{|c|c|c|c|c|c|c|c|c|c|}
\hline \multirow[b]{2}{*}{ Product } & \multicolumn{3}{|c|}{ UHT milk } & \multicolumn{3}{|c|}{ Butter } & \multicolumn{3}{|c|}{ Cheese } \\
\hline & Control & Expt & $\begin{array}{l}\text { Pooled } \\
\text { SEM }\end{array}$ & Control & Expt & $\begin{array}{l}\text { Pooled } \\
\text { SEM }\end{array}$ & Control & Expt & $\begin{array}{l}\text { Pooled } \\
\text { SEM } \\
\end{array}$ \\
\hline C4:0 & 1.01 & 0.96 & 0.014 & 29.5 & $26.6^{*}$ & 0.52 & 10.9 & $6.2^{*}$ & 0.28 \\
\hline C6:0 & 0.59 & 0.53 & 0.014 & 16.2 & $14.6^{*}$ & 0.27 & 6.2 & $3.6^{*}$ & 0.16 \\
\hline C8:0 & 0.36 & 0.31 & 0.011 & 9.4 & 8.8 & 0.17 & 3.6 & $2.3^{*}$ & 0.10 \\
\hline C10:0 & 0.77 & 0.66 & 0.026 & 19.6 & $18.1^{*}$ & 0.29 & 7.6 & $4.8^{*}$ & 0.18 \\
\hline C12:0 & 0.91 & $0.77 *$ & 0.027 & 22.6 & $20.1^{*}$ & 0.28 & 8.4 & $5.4^{*}$ & 0.12 \\
\hline C14:0 & 3.16 & $2.86^{*}$ & 0.052 & 78.7 & $72.1^{*}$ & 0.66 & 27.6 & $19.9 *$ & 0.18 \\
\hline $\mathrm{C} 14: 0$ cis -9 & 0.26 & $0.20 *$ & 0.003 & 6.5 & $4.5^{*}$ & 0.05 & 2.3 & $1.3^{*}$ & 0.01 \\
\hline C16:0 & 9.30 & $8.19 *$ & 0.034 & 223 & $185^{*}$ & 0.5 & 78.1 & $55.7^{*}$ & 0.30 \\
\hline C16:1 cis-9 & 0.69 & $0.53 *$ & 0.004 & 15.6 & $10.9 *$ & 0.04 & 5.4 & $3.6^{*}$ & 0.02 \\
\hline C18:0 & 2.86 & $1.30 *$ & 0.029 & 66.2 & $27.7^{*}$ & 0.31 & 24.5 & $9.1^{*}$ & 0.19 \\
\hline C18:1 cis-9 & 6.20 & $3.39 *$ & 0.061 & 146 & $71^{*}$ & 1.1 & 54.3 & $22.8^{*}$ & 0.30 \\
\hline C18:1 cis-11 & 0.23 & $0.35^{*}$ & 0.003 & 5.5 & $7.4^{*}$ & 0.05 & 2.0 & $2.4^{*}$ & 0.018 \\
\hline C18:1 cis-12 & 0.05 & $0.07 *$ & $<0.001$ & 1.1 & $1.3^{*}$ & 0.01 & 0.41 & $0.45^{*}$ & 0.004 \\
\hline C18:1 cis-13 & 0.04 & 0.05 & 0.002 & 0.8 & $0.9^{*}$ & 0.01 & 0.32 & $0.31^{*}$ & 0.002 \\
\hline C18:1 cis-15 & 0.01 & 0.02 & 0.003 & 0.2 & $0.5^{*}$ & 0.01 & 0.05 & $0.19^{*}$ & 0.003 \\
\hline C18:1 cis-16 & 0.01 & 0.02 & 0.004 & 0.3 & $0.7 *$ & 0.04 & 0.14 & $0.22^{*}$ & 0.004 \\
\hline C18:1 trans -4 & 0.01 & $0.02 *$ & 0.001 & 0.10 & $0.47 *$ & 0.001 & 0.04 & $0.15^{*}$ & 0.003 \\
\hline C18:1 trans -5 & 0.01 & $0.02 *$ & 0.001 & 0.07 & $0.46^{*}$ & 0.008 & 0.03 & $0.16^{*}$ & 0.004 \\
\hline $\mathrm{C} 18: 1$ trans $-6,-7,-8$ & 0.06 & $0.23 *$ & 0.001 & 1.5 & $5.3^{*}$ & 0.11 & 0.55 & $1.61^{*}$ & 0.004 \\
\hline C18:1 trans -9 & 0.06 & $0.23 *$ & 0.002 & 1.3 & $4.6^{*}$ & 0.20 & 0.54 & $1.56^{*}$ & 0.010 \\
\hline $\mathrm{C} 18: 1$ trans -10 & 0.06 & $0.30 *$ & 0.017 & 1.8 & $10.0^{*}$ & 0.85 & 0.54 & $2.44^{*}$ & 0.039 \\
\hline C18:1 trans-11 & 0.31 & $4.49 *$ & 0.018 & 6.7 & $98.8^{*}$ & 1.09 & 2.6 & $33.3^{*}$ & 0.21 \\
\hline C18:1 trans -12 & 0.07 & $0.32 *$ & 0.002 & 1.6 & $8.1^{*}$ & 0.03 & 0.62 & $2.31^{*}$ & 0.014 \\
\hline C18:1 trans $-13,-14$ & 0.10 & $0.33 *$ & 0.003 & 1.8 & 4.5 & 0.95 & 0.90 & $2.05^{*}$ & 0.041 \\
\hline $\mathrm{C} 18: 1$ trans -15 & 0.04 & $0.09 *$ & 0.002 & 0.7 & $1.1^{*}$ & 0.06 & 0.30 & $0.56^{*}$ & 0.015 \\
\hline C18:1 trans-16 & 0.06 & $0.05^{*}$ & 0.003 & 1.4 & $1.1^{*}$ & 0.02 & 0.56 & $0.37 *$ & 0.007 \\
\hline C18:1 cis total & 6.53 & $3.87 *$ & 0.068 & 153.5 & $81.3 *$ & 1.10 & 57.1 & $26.2^{*}$ & 0.32 \\
\hline C18:1 trans total & 0.76 & $6.08 *$ & 0.042 & 16.9 & $134.4^{*}$ & 1.12 & 6.7 & $44.5^{*}$ & 0.22 \\
\hline C18:1 total & 7.29 & $9.95 *$ & 0.108 & 170 & $216^{*}$ & 1.3 & 62.8 & $70.7^{*}$ & 0.53 \\
\hline $\mathrm{C} 18: 2$ cis -9, cis -12 & 0.52 & $0.48 *$ & 0.009 & 12.0 & $9.7^{*}$ & 0.09 & 4.24 & $3.15^{*}$ & 0.026 \\
\hline $\mathrm{C} 18: 2$ trans -11, cis -15 & 0.02 & $0.14^{*}$ & 0.003 & 0.6 & $3.3^{*}$ & 0.02 & 0.21 & $1.02 *$ & 0.004 \\
\hline C18:2 total $^{2}$ & 0.66 & $0.85^{*}$ & 0.016 & 15.6 & $17.9^{*}$ & 0.18 & 5.56 & $5.87^{*}$ & 0.027 \\
\hline cis-9, trans-11 CLA & 0.15 & $1.40^{*}$ & 0.014 & 3.4 & $29.2^{*}$ & 0.16 & 1.18 & $9.80^{*}$ & 0.073 \\
\hline CLA total & 0.16 & $1.47 *$ & 0.014 & 3.9 & $31.3^{*}$ & 0.23 & 1.39 & $10.51^{*}$ & 0.080 \\
\hline C18:3 (n-3) & 0.09 & $0.06^{*}$ & 0.003 & 2.0 & $1.3^{*}$ & 0.02 & 0.72 & $0.39^{*}$ & 0.010 \\
\hline $\mathrm{C} 20: 0$ & 0.04 & 0.04 & 0.002 & 0.9 & $0.8^{*}$ & 0.02 & 0.37 & 0.32 & 0.008 \\
\hline C20:5 (n-3) & 0.01 & $0.03^{*}$ & 0.001 & 0.3 & $0.7 *$ & 0.01 & 0.11 & $0.22^{*}$ & 0.004 \\
\hline $\mathrm{C} 22: 0$ & 0.01 & $0.03 *$ & 0.001 & 0.3 & $0.5^{*}$ & 0.01 & 0.13 & $0.20^{*}$ & 0.005 \\
\hline $\mathrm{C} 22: 5(\mathrm{n}-3)$ & 0.03 & $0.07 *$ & 0.002 & 0.6 & $1.2^{*}$ & 0.02 & 0.22 & $0.45^{*}$ & 0.006 \\
\hline C22:6 (n-3) & 0.00 & $0.03 *$ & 0.002 & 0.04 & $0.49 *$ & 0.015 & 0.03 & $0.17^{*}$ & 0.007 \\
\hline C24:0 & 0.01 & 0.01 & 0.001 & 0.2 & 0.2 & 0.01 & 0.09 & $0.07^{*}$ & 0.001 \\
\hline Glycerol & 4.27 & $4.45^{*}$ & 0.018 & 105 & 105 & 0.2 & 38.0 & $31.2^{*}$ & 0.12 \\
\hline Total $\leq \mathrm{C} 14$ & 7.25 & $6.45^{*}$ & 0.150 & 187 & $168^{*}$ & 1.9 & 68.6 & $44.4^{*}$ & 1.05 \\
\hline Total saturates & 20.27 & $16.82^{*}$ & 0.128 & 496 & $402^{*}$ & 1.6 & 178 & $116^{*}$ & 0.6 \\
\hline Total MUFA & 8.37 & $10.87 *$ & 0.100 & 196 & $235^{*}$ & 1.3 & 71.8 & $76.8^{*}$ & 0.55 \\
\hline Total PUFA & 1.10 & $2.86^{*}$ & 0.050 & 24.9 & $59.4^{*}$ & 0.47 & 8.9 & $20.0^{*}$ & 0.14 \\
\hline Total (n-3) PUFA & 0.16 & $0.42^{*}$ & 0.017 & 3.31 & $7.74^{*}$ & 0.092 & 1.21 & $2.75^{*}$ & 0.034 \\
\hline Total $(n-6)$ PUFA & 0.63 & 0.61 & 0.013 & 14.1 & $12.2^{*}$ & 0.22 & 5.01 & $4.03^{*}$ & 0.042 \\
\hline Total fatty acids & 29.7 & $30.5^{*}$ & 0.018 & 717 & $697^{*}$ & 0.2 & 259 & $212^{*}$ & 0.1 \\
\hline
\end{tabular}

${ }^{1} \mathrm{CLA}=$ Conjugated linoleic acid, MUFA = monounsaturated fatty acids, PUFA = polyunsaturated fatty acids.

${ }^{2}$ Sum of C18:2 excluding isomers of CLA.

*Significant $(\mathrm{P}<0.05)$ difference from control mean.

In contrast to the current study, feeding fishmeal to enhance milk fat $n-3$ fatty acid concentrations had no effect on milk protein content, or on the fat, moisture, or protein contents of Cheddar cheese manufactured from this milk, although there was a trend towards a lower fat content (Avramis et al., 2003). Avramis et al. (2003) also noted both softer fat and smaller, more uniformly sized milk fat globules in cream prepared from the milk of cows fed on fishmeal. However, the fatty acid profiles of milk or dairy products were not 
A)

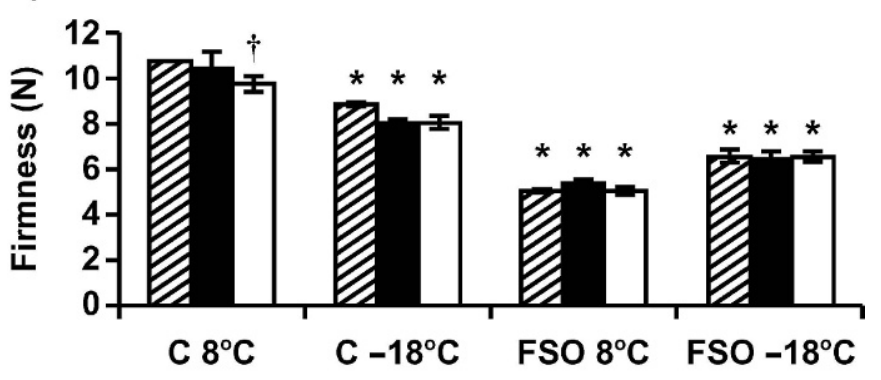

B)

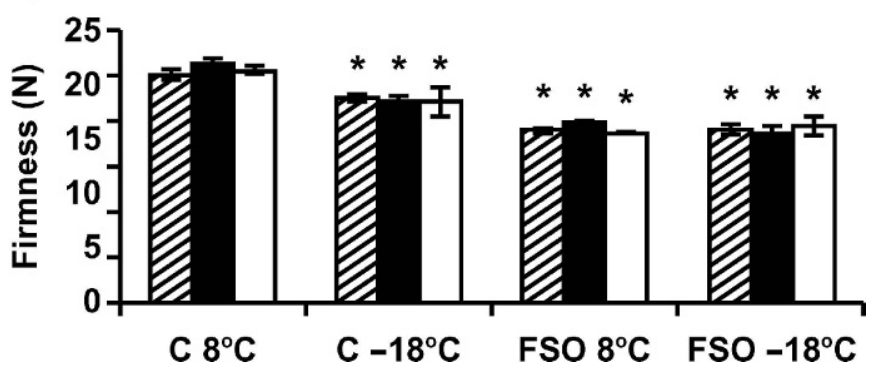

Figure 1. Firmness of control and CLA-enriched (A) cheese and (B) butter stored at 8 or $-18^{\circ} \mathrm{C}$ for 1,3 and $6 \mathrm{wk}$. Data are mean \pm SEM for $\mathrm{n}=3$ samples. Samples of cheese and butter were stored for 1 wk (diagonal line), 3 wk (black box) or 6 wk (white box) and firmness assessed as described in the Materials and Methods. *Denotes significantly different from control at $8^{\circ} \mathrm{C}$ at the corresponding time point $(P<0.05)$. †Denotes significantly different from week 1 $(P<0.05)$.

reported in that study, so it is not possible to establish if the changes in milk fat globule size were associated with specific alterations in milk fatty acid composition. Nevertheless, fat globules in the CLA-enriched milk in the current study were significantly smaller and had a more uniform size distribution than those in the control milk (Table 4).

\section{Fatty Acid Composition of Cheese and Butter}

Consistent with the differences in fatty acid composition of raw milk from cows fed the control and experimental diets, experimental UHT milk, cheese, and butter contained approximately ninefold higher concentrations of total CLA compared with the corresponding control products (Table 5). Accounting for differences in the fat content of control and experimental products indicated that the experimental UHT milk, butter, and cheese contained 9.3, 8.0, and 7.6 times the amount of total CLA compared with the corresponding controls (Table 6). In addition, experimental products contained approximately 8.0-, 8.0-, and 6.7-fold (for UHT milk, butter, and cheese, respectively) more trans C18:1 and 2.6, 2.3, and 2.3 times more total n-3 fatty acids than the control products. Furthermore, experimental UHT milk, butter, and cheese contained proportionately $0.55,0.49$, and 0.42 , and $0.83,0.81$, and 0.65 of the amount of cis-9 C18:1 and total saturated fatty acids in the control products (Table 6).

\section{Physical Properties of Cheese and Butter}

Firmness of cheese and butter, as determined by texture profile analysis, is presented in Figure 1. This analysis revealed differences in the texture of control and experimental products, as well as a differential effect of freezing on firmness. The CLA-enriched experimental cheese was significantly softer than the control, irrespective of storage temperature (Figure 1A). Although the firmness of the control cheese signifi-

Table 7. Results of triangle tests used to evaluate differences between the control and experimental dairy products stored at either $8^{\circ} \mathrm{C}$ or $-18^{\circ} \mathrm{C}$.

\begin{tabular}{llll}
\hline Product & Sample comparisons ${ }^{1}$ & $\begin{array}{l}\text { No. of correct } \\
\text { observations }\end{array}$ & $P$-value \\
\hline Cheese & Expt vs. Control $\left(8^{\circ} \mathrm{C}\right)$ & 13 & NS \\
& Expt vs. Control $\left(-18^{\circ} \mathrm{C}\right)$ & 11 & NS \\
& Expt $\left(-18^{\circ} \mathrm{C}\right)$ vs. Expt $\left(8^{\circ} \mathrm{C}\right)$ & 15 & NS \\
Butter & Control $\left(-18^{\circ} \mathrm{C}\right)$ vs. Control $\left(8^{\circ} \mathrm{C}\right)$ & 14 & NS \\
& Expt vs. Control $\left(8^{\circ} \mathrm{C}\right)$ & 24 & $<0.001$ \\
& Expt vs. Control $\left(-18^{\circ} \mathrm{C}\right)$ & 20 & NS \\
UHT milk & Expt $\left(-18^{\circ} \mathrm{C}\right)$ vs. Expt $\left(8^{\circ} \mathrm{C}\right)$ & 16 & NS \\
\hline
\end{tabular}

${ }^{1}$ Control and Expt refer to experimental UHT milk, butter or cheese prepared from milk from corn silage based diets containing 0 or $45 \mathrm{~g} / \mathrm{kg}$ of DM of a mixture (1:2, wt/w) of fish oil and sunflower oil, respectively.

${ }^{2}$ Refers to the number of occasions the odd sample in triangle tests was correctly identified (out of a possible maximum of $\mathrm{n}=36$ ) by a 20 member consumer taste panel.

${ }^{3}$ Probability of significant differences determined using tabulated Critical Number (minimum) of Correct Answers. 
A)

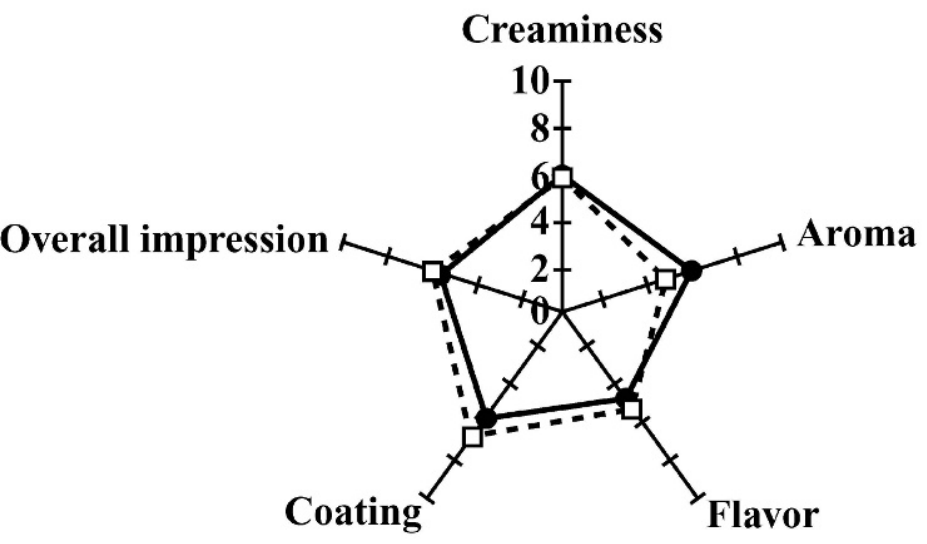

B)

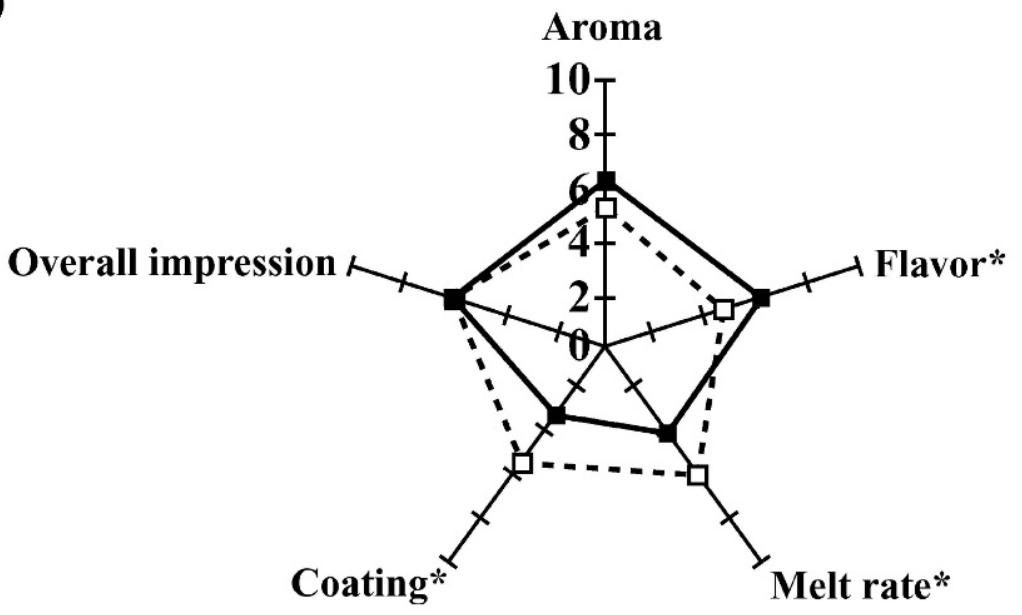

C)

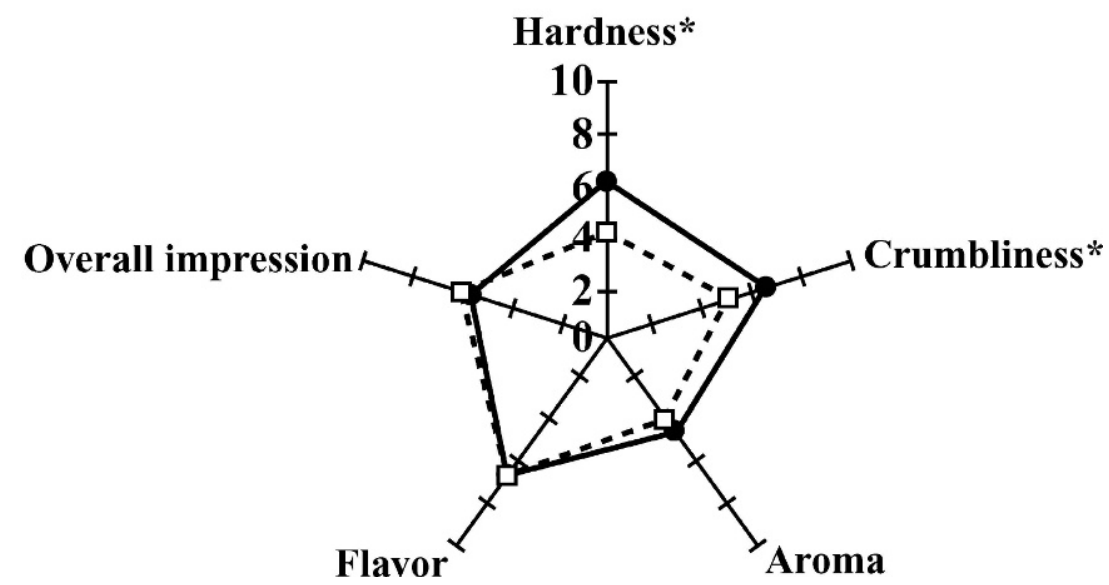

Figure 2. Sensory attribute ratings of control and CLA-enriched (A) milk (B) butter, and (C) cheese. Data are the means of taste panel scores for the control (---) and CLA-enriched $(\mathrm{G})$ products. ${ }^{*}$ Denotes significant $(P<0.05)$ difference for a given attribute between samples. 
cantly decreased upon freezing, that of the experimental cheese increased (Figure 1A). The only significant effect of time over the 6 -wk storage period was a decrease in the firmness of control cheese after a 6 -wk storage at $8^{\circ} \mathrm{C}$ compared with wk 1 (Figure $1 \mathrm{~A}$ ).

The experimental CLA-enriched butter was significantly softer (approximately $30 \%$ ) than the control butter (Figure 1B). Freezing had no effect on the firmness of the CLA-enriched butter, but reduced that of the control butter (Figure 1B). The softer texture of the CLA-enriched butter compared with the control is consistent with previous studies (Baer et al., 2001; Ryhänen et al., 2005) and probably reflects the higher unsaturated fatty acid content of CLA enriched milk fat. Furthermore, storage temperature did not affect the texture, suggesting that the product would have good spreadability. A butter which has a greater spreadability and good storage characteristics is potentially attractive to consumers.

\section{Sensory Characteristics of CLA-Enriched Dairy Products}

Consumer triangle tests indicated no differences between the control and CLA-enriched cheeses (Table 7). However, there was a significant difference between the CLA-enriched and the control UHT milk; 23 out of 36 observations correctly identified the different milk sample (Table 7). The control and CLA-enriched butters stored at $8^{\circ} \mathrm{C}$ were also found to be significantly different (Table 7). Nevertheless, no off flavors or rancid notes were detected by any of the consumer panelists and the reasons for the differences detected are not clear.

There is a lack of detailed sensory profiling and analysis of the storage characteristics of CLA-enriched dairy products reported in the literature. In the current study, sensory profiling identified no significant differences in any sensory attributes between the control and CLA-enriched UHT milks, despite the fact that triangle tests had highlighted a difference (Figure $2 \mathrm{~A})$. It is possible that the difference in fat globule size may have resulted in the difference between control and experimental UHT milk in the triangle testing, although if there was an effect of fat globule size on mouthfeel, it might be expected that this would be manifested as a difference in creaminess or coating, which was not the case. The CLA-enriched butter was assessed as having a significantly faster melt rate and higher coating, while the control butter was deemed to have a significantly greater flavor (Figure $2 \mathrm{~B}$ ). The higher melt rate is perhaps consistent with the CLAenriched butter being softer. However, there was no significant difference in the overall impression of the control and experimental butter (Figure 2B). The CLAenriched cheese was found to be significantly less firm and less crumbly than the control cheese (Figure 2C), which agrees with the results from the texture analysis. However, there were no differences in flavor, aroma or overall impression of the two cheeses (Figure 2C).

Thus, the CLA-enhanced butter and cheese were less firm than control products and differed with respect to certain sensory attributes, but the overall flavor of the CLA-enriched products was not significantly different from the corresponding controls. This study therefore demonstrates the feasibility of producing CLA-enriched dairy products with acceptable sensory and storage characteristics. The enrichment described in this "proof-of-concept" study, while not feasible on a large scale, could deliver levels of cis-9,trans-11 CLA that have been reported to affect immune function and blood lipid levels in humans. Future work needs to consider the effect of CLA-enriched dairy products on human health and to weigh this against the challenges in attaining consistently high levels of CLA enrichment, the associated increases in production costs, and potential negative effects on animal performance and health.

\section{ACKNOWLEDGMENTS}

This work was funded by a grant (number EFH/ 16) from the BBSRC, DEFRA, SEERAD and the Milk Development Council, under the Eating, Food and Health LINK scheme, to P. C. Calder, P. Yaqoob, D. E. Beever, and C. M. Williams.

\section{REFERENCES}

Abu-Ghazaleh, A. A., D. J. Schingoethe, A. R. Hippen, and K. F. Kalscheur. 2003. Milk conjugated linoleic acid response to fish oil supplementation of diets differing in fatty acid profiles. J. Dairy Sci. 86:944-953.

Abu-Ghazaleh, A. A., D. J. Schingoethe, A. R. Hippen, and K. F. Kalscheur. 2004. Conjugated linoleic acid increases in milk when cows fed fish meal and extruded soybeans for an extended period of time. J. Dairy Sci. 87: 1758-1766.

Abu-Ghazaleh, A. A., D. J. Schingoethe, A. R. Hippen, and L. A. Whitlock. 2002. Feeding fish meal and extruded soybeans enhances the conjugated linoleic acid (CLA) content of milk. J. Dairy Sci. 85:624-631.

Agricultural and Food Research Council. 1993. Energy and Protein Requirements of Ruminants. An Advisory Manual Prepared by the AFRC Technical Committee on Responses to Nutrients. CAB Int., Wallingford, UK.

AOAC. 1990. Official Methods of Analysis. 15th ed. Assoc. Off. Anal. Chem., Arlington, VA.

Atherton, H. V., and J. A. Newlander. 1977. The Chemistry and Testing of Milk and Dairy Products. 4th ed. AVI Publ. Co., Inc., Westport, CT.

Avramis, C. A., H. Wang, B. W. McBride, T. C. Wright, and A. R. Hill. 2003. Physical and processing properties of milk, butter and cheddar cheese from cows fed supplemental fish meal. J. Dairy Sci. 86:2568-2576. 
Baer, R. J., J. Ryali, D. J. Schingoethe, K. M. Kasperson, D. C. Donovan, A. R. Hippen, and S. T. Franklin. 2001. Composition and properties of milk and butter from cows fed fish oil. J. Dairy Sci. 84:345-352.

Bauman, D. E., D. M. Barbano, D. A. Dwyer, and J. M. Griinari. 2000. Technical Note: Production of butter with enhanced conjugated linoleic acid for use in biomedical studies with animal models. J. Dairy Sci. 83:2422-2425.

Chilliard, Y. A., A. Ferlay, and M. Doreau. 2001. Effect of different types of forages, animal fat or marine oils in cow's diet on milk fat secretion and composition, especially conjugated linoleic acid (CLA) and polyunsaturated fatty acids. Livest. Prod. Sci. $70: 31-48$

Chouinard, P. Y., L. Corneau, W. R. Butler, Y. Chilliard, J. K. Drackley, and D. E. Bauman. 2001. Effect of dietary lipid source on conjugated linoleic acid concentrations in milk fat. J. Dairy Sci. 84:680-690.

Christie, W. W. 1982. A simple procedure for rapid transmethylation of glycerolipids and cholesteryl esters. J. Lipid Res. 23:10721075.

Coulon, J. B., and B. Remond. 1991. Variations in milk output and milk protein-content in response to the level of energy supply to the dairy-cow-A review. Livest. Prod. Sci. 29:31-47.

Dhiman, T. R., Anand, G. R., Satter, L. D. and M. W. Pariza. 1999a. Conjugated linoleic acid content of milk from cows fed different diets. J. Dairy Sci. 82: 2146-2156.

Dhiman, T. R., E. D. Helmink, D. J. McMahon, R. L. Fife, and M. W. Pariza. 1999b. Conjugated linoleic acid content of milk and cheese from cows fed extruded oilseeds. J. Dairy Sci. 82:412-419.

Dhiman T. R., L. D. Satter, M. W. Pariza, M. P. Galli, K. Albright, and M. X. Tolosa. 2000. Conjugated linoleic acid (CLA) content of milk from cows offered diets rich in linoleic and linolenic acid. J. Dairy Sci. 83:1016-1027.

Egan, H., R. S. Kirk, and R. Sawyer. 1981. Pearson's Chemical Analysis of Foods. 8th ed. Longman Scientific and Technical, London, UK.

Jenkins, T. C. 1993. Lipid metabolism in the rumen. J. Dairy Sci. 76:3851-3863.

Kelly, M. L., Berry, J. R., Dwyer, D. A., Griinari, J. M., Chouinard, P. Y., van Amburgh, M. E. and D.E. Bauman. 1998a. Dietary fatty acid sources affect conjugated linoleic acid concentrations in milk from lactating dairy cows. J. Nutr. 128: 881-885.

Kelly, M. L., Kolver, E. S., Bauman, D. E., van Amburgh, M. E. and L.D. Muller. 1998b. Effect of intake of pasture on concentrations of conjugated linoleic acid in milk of lactating cows. J. Dairy Sci. 81:1630-1636.

Kitessa S. M., S. K. Gulati, G. C. Simos, J. R. Ashes, T. W. Scott, E. Fleck, and P. C. Wynn. 2004. Supplementation of grazing dairy cows with rumen-protected tuna oil enriches milk fat with n-3 fatty acids without affecting milk production or sensory characteristics. Br. J. Nutr. 91:271-277.

Khanal, R. C., T. R. Dhiman, A. L. Ure, C. P. Brennand, R. L. Boman, and D. J. McMahon. 2005. Consumer acceptability of conjugated linoleic acid-enriched milk and cheddar cheese from cows grazing on pasture. J. Dairy Sci. 88:1837-1847.

Khosla, P., and T. V. Fungwe. 2001. Conjugated linoleic acid: Effects on plasma lipids and cardiovascular function. Curr. Opin. Lipidol. 12:31-34.

Lawless, F., J. J. Murphy, D. Harrington, R. Devery, and C. Stanton. 1998. Elevation of conjugated cis-9, trans-11-octadecadienoic acid in bovine milk because of dietary supplementation. J. Dairy Sci. 81:3259-3267.

Lawson, R. E., A. R. Moss, and D. I. Givens. 2001. The role of dairy products in supplying conjugated linoleic acid to man's diet: A review. Nutr. Res. Rev. 14:153-172.

Lock, A. L., and K. J. Shingfield. 2004 Optimising milk composition. Pages 107-188 in Dairying-Using Science to Meet Consumers' Needs. E. Kebreab, J. Mills, and D. E. Beever, ed. Br. Soc. Anim. Sci., Publ. 29, Nottingham Univ. Press, Loughborough, UK.
Loor, J. J., J. H. Herbein, and C.E. Polan. 2002. Trans 18:1 and 18:2 isomers in blood plasma and milk fat of grazing cows fed a grain supplement containing solvent-extracted or mechanically extracted soybean meal. J. Dairy Sci. 85:1197-1207.

Lumley, I. D. 1993. Vitamin analysis in food. Pages 70-85 in The Technology of Vitamins in Food. P. Ottaway, ed. Kluwer Academic/ Plenum Publishers, London, UK.

Lynch, J. M., A. L. Lock, D. A. Dwyer, R. Noorbakhash, D. M. Barbano, and D. E. Bauman. 2005. Flavor and stability of pasteurized milk with elevated levels of conjugated linoleic acid and vaccenic acid. J. Dairy Sci. 88:489-498.

Malpuech-Brugere, C., W. P. Verboeket-van de Venne, R. P. Mensink, M. A. Arnal, B. Morio, M. Brandolini, A. Saebo, T. S. Lassel, J. M. Chardigny, J. L. Sebedio, and B. Beaufrere. 2004. Effects of two conjugated linoleic acid isomers on body fat mass in overweight humans. Obesity Res. 12:591-598.

Meilgaard, M., G. V. Civille, and B. T. Carr. 1999. Pages 43-57 in Sensory Evaluation Techniques. 3rd ed. CRC Press, Boca Raton, FL.

Offer, N. W., M. Marsden, J. Dixon, B. K. Speake, and F. E. Thacker. 1999. Effect of dietary fat supplements on levels of n-3 polyunsaturated fatty acids, trans acids and conjugated linoleic acid in bovine milk. Anim. Sci. 69:613-625.

Palmquist, D. L., D. A. Beaulieu, and D. M. Barbano. 1993. Feed and animal factors influencing milk fat composition. J. Dairy Sci. 76:1753-1771.

Parodi, P. W. 1999. Conjugated linoleic acid and other Anticarcinogenic agents of bovine milk fat. J. Dairy Sci. 82:1339-1349.

Porter, M. G., D. C. Patterson, R. W. J. Steen, and F. J. Gordon. 1984. Determination of dry matter and gross energy of grass silage. Proc. 7th Silage Conf., The Queen's Univ., Belfast.

Ramaswamy, N., R. J. Baer, D. J. Schingoethe, A. R. Hippen, K. M. Kasperson, and L. A. Whitlock. 2001. Consumer evaluation of milk high in conjugated linoleic acid. J. Dairy Sci. 84:1607-1609.

Roche, H. M., E. Noone, A. Nugent, and M. J. Gibney. 2001. Conjugated linoleic acid: A novel therapeutic nutrient? Nutr. Res. Rev. $14: 173-187$.

Rossell, J. B. 1989. Intermediate shelf life products as illustrated by fats and fatty foods. Food Sci. Technol. Today 3:235-240.

Ryhänen, E.-L., K. Tallavaara, J. M. Griinari, S. Jaakkola, S. Mantere-Alhonen, and K. J. Shingfield. 2005. Production of conjugated linoleic acid enriched milk and dairy products from cows receiving grass silage supplemented with a cereal-based concentrate containing rapeseed oil. Int. Dairy J. 15:207-217.

Shingfield, K. J., S. Ahvenjärvi, V. Toivonen, A. Ärölä, K. V. V. Nurmela, P. Huhtanen, and J. M. Griinari. 2003. Effect of fish oil on biohydrogenation of fatty acids and milk fatty acid content in cows. Anim. Sci. 77:165-179.

Shingfield, K. J., C. K. Reynolds, B. Lupoli, V. Toivonen, M. P. Yurawecz, P. Delmonte, J. M. Griinari, A. S. Grandison, and D. E. Beever. 2005. Effect of forage type and proportion of concentrate in the diet on milk fatty acid composition in cows given sunflower and fish oil. Anim. Sci. 80:225-238.

Statutory Instruments. 1982. Number 1144. Agriculture. The Feeding Stuffs (Sampling and Analysis) Regulations. Her Majesty's Stationary Office, London.

Statutory Instruments. 1985. Number 1119. Agriculture. The Feeding Stuffs (Sampling and Analysis Amendment) Regulations. Her Majesty's Stationary Office, London.

Terpstra, A. H. M. 2004. Effect of conjugated linoleic acid on body composition and plasma lipids in humans: An overview of the literature. Am. J. Clin. Nutr. 79:352-361.

Tricon, S., G. C. Burdge, S. Kew, T. Banerjee, J. J. Russell, E. L. Jones, R. F. Grimble, C. M. Williams, P. C. Calder, and P. Yaqoob. 2004a. Effects of cis-9, trans-11 and trans-10, cis-12 conjugated linoleic acid on immune function in healthy humans. Am. J. Clin. Nutr. 80:1626-1633.

Tricon, S., G. C. Burdge, J. J. Russell, E. L. Jones, R. F. Grimble, C. M. Williams, P. Yaqoob, and P. C. Calder. 2004b. Opposing 
effects of cis-9,trans-11 and trans-10,cis-12 CLA on blood lipids in healthy humans. Am. J. Clin. Nutr. 80:614-620.

Watkins, B. A. and Y. Li. 2003 CLA in functional food: Enrichment of animal products. Pages 174-188 in Advances in Conjugated Linoleic Acid Research. Vol. II. J. L. Sebedio, W. W. Christie, and R. Adolf, ed. AOCS Press, Champaign, IL.

Whitlock, J. A., D. J. Schingoethe, A. R. Hippen, K. F. Kalscheur, R. J. Baer, N. Ramaswamy, and K. M. Kasperson. 2002. Fish oil and extruded soybeans fed in combination increase conjugated linoleic acid in milk of dairy cows more than when fed separately. J. Dairy Sci. 85:234-243.

Wu, Z., and J. T. Huber. 1994. Relationship between dietary-fat supplementation and milk protein-concentration in lactating cows-A review. Livest. Prod. Sci. 39:141-155.

Zock, P. L., and M. B. Katan. 1992. Hydrogenation alternatives: Effects of trans fatty acids and stearic acid versus linoleic acid on serum lipids and lipoproteins in humans. J. Lipid Res. $33: 399-410$ 